\title{
Mast cell tryptase potentiates histamine-induced contraction in human sensitized bronchus
}

\author{
P.R.A. Johnson*, A.J. Ammit*\#, S.M. Carlin*, C.L. Armour\#, \\ G.H. Caughey**, J.L. Black*
}

Mast cell tryptase potentiates histamine-induced contraction in human sensitized bronchus. P.R.A. Johnson, A.J. Ammit, S.M. Carlin, C.L. Armour, G.H. Caughey, J.L. Black. @ERS Journals Ltd 1997.

ABSTRACT: The mast cell plays a pivotal role in the early asthmatic response via release of mediators, which directly influence airway smooth muscle tone. Canine mast cell tryptase has been reported to potentiate the contractile response of canine isolated airways to histamine. The aim of this study was to investigate whether human mast cell tryptase potentiated contractile responses in human isolated bronchi.

The effect of tryptase differed according to the sensitization status of the bronchi. In lung tissue from sensitized patients (those whose bronchial tissue contracted in response to the application of any of four common antigens) $90 \mathrm{ng} \cdot \mathrm{mL}^{-1}$ of human purified lung tryptase markedly potentiated the contractile response to histamine. The maximal response as a percentage of maximal contraction to acetylcholine was $80 \pm 8 \%$ in control tissues and $119 \pm 6 \%$ in tryptase treated tissues $(n=4 ; p<0.05)$. Tryptase, at a dose of $200 \mathrm{ng} \cdot \mathrm{mL}^{-1}$, also potentiated responses but to a lesser degree, $100 \pm 5 \%(n=4 ; p<0.05)$. In nonsensitized bronchi, neither 90 nor $200 \mathrm{ng} \cdot \mathrm{mL}^{-1}$ tryptase had any significant effect on histamine responses. The increased response in the presence of tryptase in sensitized tissue was inhibited by the calcium voltage-dependent channel antagonist, verapamil $\left(1^{-6} \mathrm{M}\right)$.

We have shown, for the first time, that human mast cell tryptase potentiates contraction in sensitized bronchi via a calcium-related mechanism. These findings provide a link between a mast cell derived product and in vitro human airway hyperresponsiveness.

Eur Respir J., 1997; 10: 38-43.
Depts of *Pharmacology and \#Pharmacy, The University of Sydney, NSW, Australia. **Cardiovascular Research Institute, Dept of Medicine, University of California, San Francisco, CA, USA.

Correspondence: J.L. Black

Dept of Pharmacology

The University of Sydney NSW 2006

Australia

Keywords: Human bronchus hyperresponsiveness

mast cell tryptase

sensitization

\section{Received: March 251996}

Accepted after revision September 271996

Supported by The National Health and Medical Research Council of Australia, The Asthma Foundation of New South Wales and NIH project grants HL-24136 and HL-54774. GC is the recipient of an ALA Career Investigator Award and AA is the recipient of the Martin Hardie Fellowship from the Asthma Foundation of NSW.
Mast cells are pivotal to the immediate or early response in asthma, and contain mediators which have profound effects on airway smooth muscle tone. The relationship between mast cell products and a heightened contraction of human airway smooth muscle, which could contribute to airway hyperresponsiveness, has not been established in human airways. Although there is some evidence to support in vitro differences between asthmatic and nonasthmatic muscle [1-5], results are conflicting [2, 3, 6, 7]. In 1989, SEKIZAWA et al. [8] observed that supernatants derived from canine degranulated mast cells markedly increased the contractile response of canine airways to histamine. They extended these findings to report that the changes were due to tryptase, a proteolytic enzyme contained in mast cells. More recently, TANAKA et al. [9] reported that a relatively selective tryptase inhibitor reduces bronchoconstriction and hyperresponsiveness in a model of allergic asthma in sheep. Thus, in animal tissue, there is a link between the effects of a specific mast cell product, tryptase, and in vitro hyperresponsiveness. The aim of the current study was to investigate whether the same phenomenon occurs in human airways with human mast cell tryptase.

\section{Methods}

Human lung tissue was obtained from 11 patients, six of whom were undergoing lobectomy or pneumonectomy (usually for suspected carcinoma) and five who were undergoing pulmonary transplantation. Details of the patients are presented in table 1. Approval for all experiments with human lung was provided by the Human Ethics Committee of the University of Sydney and the Central Sydney Area Health Service. Eight bronchial rings, measuring 3-5 $\mathrm{mm}$ in internal diameter and $4 \mathrm{~mm}$ in length, were dissected from the tissue from each patient and stored overnight at $4^{\circ} \mathrm{C}$ in Krebs Henseleit solution (composition in mmol. $\mathrm{L}^{-1}$ : $\mathrm{NaCl} 118.4, \mathrm{KCl}$ 4.7, $\mathrm{CaCl}_{2} \cdot 2 \mathrm{H}_{2} \mathrm{O} 2.5, \mathrm{MgSO}_{4} \cdot 7 \mathrm{H}_{2} \mathrm{O} 1.2, \mathrm{KH}_{2} \mathrm{PO}_{4} 1.2$, $\mathrm{NaHCO}_{3} 25.0$, and D-glucose 11.1) aerated with 5\% $\mathrm{CO}_{2}$ in $\mathrm{O}_{2}$ (carbogen). On the day following retrieval, the tissues were suspended in $5 \mathrm{~mL}$ organ baths containing Krebs Henseleit solution, bubbled with carbogen and maintained at $37^{\circ} \mathrm{C}$. A load of $1-2 \mathrm{~g}$ was placed on the tissues as determined by tissue size [10], as we have previously shown that these loads are optimal in tissues of these measurements [11]. Tissues were washed at 15 min intervals until a stable tone was established. Changes 
Table 1. - Characteristics of patients from whom tissue was obtained

\begin{tabular}{|c|c|c|c|c|}
\hline $\begin{array}{l}\mathrm{Pt} \\
\text { No. }\end{array}$ & Condition & Sex & $\begin{array}{l}\text { Age } \\
\text { yrs }\end{array}$ & $\begin{array}{l}\text { Sensitization } \\
\text { status* }\end{array}$ \\
\hline 1 & $\begin{array}{l}\text { Left pneumonectomy, } \\
\text { carcinoma }\end{array}$ & M & 77 & $S$ \\
\hline 2 & $\begin{array}{l}\text { Transplant recipient } \\
\text { cystic fibrosis }\end{array}$ & M & 17 & $S$ \\
\hline 3 & $\begin{array}{l}\text { Aspergillosis, left upper } \\
\text { lobectomy }\end{array}$ & M & 63 & $S$ \\
\hline 4 & Left upper lobe tumour & M & 48 & $\mathrm{~S}$ \\
\hline 5 & $\begin{array}{l}\text { Transplant recipient, } \\
\text { Eisenmenger's syndrome }\end{array}$ & $\mathrm{F}$ & 31 & NS \\
\hline 6 & $\begin{array}{l}\text { Transplant recipient, } \\
\text { cystic fibrosis }\end{array}$ & M & 41 & NS \\
\hline 7 & $\begin{array}{l}\text { Transplant recipient, } \\
\text { emphysema }\end{array}$ & $\mathrm{F}$ & 53 & NS \\
\hline 8 & Transplant donor & $\mathrm{F}$ & 33 & NS \\
\hline 9 & Carcinoma & M & 50 & $\mathrm{~S}$ \\
\hline 10 & Carcinoma & M & 68 & $\mathrm{~S}$ \\
\hline 11 & Carcinoma & M & 72 & $\mathrm{~S}$ \\
\hline
\end{tabular}

*: as assessed by the presence or absence of a contraction to antigen in vitro. Pt: patient; M: male; F: female; S: sensitized; NS: nonsensitized.

in tension were measured isometrically using Grass FTO3 force transducers and recorded on a Grass 7P polygraph (Grass Instruments, Quincy, MA, USA).

Sensitization status was assessed, as described previously $[12,13]$, in two bronchial rings from each patient. Ten microlitres of a solution of Dermatophagoides pteronyssinus, Timothy grass pollen, Alternaria tenuis and cat pelt allergens to which more than $97 \%$ of the atopic population of Australia exhibits a positive skinprick test [14], were added sequentially to the bath. Contraction in response to any of these antigens indicated that the tissue was sensitized $[12,13]$. If tissues from a patient did not contract to any of these antigens but contracted to the subsequent addition of acetylcholine $(1 \mathrm{mM})$, then these tissues were classified as nonsensitized $[12,13]$.

\section{Assay of tryptase activity}

Mast cell derived tryptase from a human lung extract was prepared in the laboratory by one of the research team (GC) using the method described by HARTMANN et al. [15], and was transported to Australia on dry ice. As tryptase is a heat labile tetrameric enzyme (E.C. 3.4.21.59; $134 \mathrm{kDa}$ ) its activity was determined spectrophotometrically, in the laboratories in Sydney, by measuring the rate of hydrolysis of the chromogenic substrate, N-pTosyl-Gly-Pro-Lys-p-Nitroanilide with a molar extinction coefficient $=8,800$. Two microlitres of tryptase was added to $1 \mathrm{~mL}$ of reaction mixture containing $0.05 \mathrm{M}$ Tris- $\mathrm{HCl}(\mathrm{pH} 7.6), 0.12 \mathrm{M} \mathrm{NaCl}, 20 \mu \mathrm{g} \cdot \mathrm{mL}^{-1}$ heparin and $0.1 \mathrm{mM}$ N-p-Tosyl-Gly-Pro-Lys-p-Nitroanilide at $37^{\circ} \mathrm{C}$. The rate of change of absorbance (at $405 \mathrm{~nm}$ ) was recorded using an LKB Novaspec Model 4049 spectrophotometer (Biochrom, Cambridge, UK). For addition to the organ bath, tryptase activity was assessed (see Results) and prepared as $9 \mu \mathrm{g} \cdot \mathrm{mL}^{-1}$ aliquots in a buffer of $10 \mathrm{mM}$ bis-Tris, $\mathrm{pH} 6.1$, with $0.5 \mathrm{M} \mathrm{NaCl}$ and 60 $\mu \mathrm{g} \cdot \mathrm{mL}^{-1}$ heparin. These aliquots were stored at $-70^{\circ} \mathrm{C}$ until use.

\section{Responses to histamine}

In the remaining six tissues, an initial response to a maximal concentration of acetylcholine $(1 \mathrm{mM})$ was elicited and, after the contraction had reached a plateau, the tissues were washed repeatedly until baseline tension was re-established. Tissues then received $250 \mu \mathrm{g}$ heparin, to stabilize the tryptase [8], followed $15 \mathrm{~min}$ later either by tryptase, at a concentration of $90 \mathrm{ng} \cdot \mathrm{mL}^{-1}$ [8] or 200 $\mathrm{ng} \cdot \mathrm{mL}^{-1}$ (the highest concentration that could be achieved with the tryptase available), or by appropriate volumes of tryptase buffer (10 mM bis-Tris, $\mathrm{pH} 6.1$, with $0.5 \mathrm{M}$ $\mathrm{NaCl}$ and $60 \mu \mathrm{g} \cdot \mathrm{mL}^{-1}$ heparin). After an equilibration period of $15 \mathrm{~min}$, a cumulative concentration-response curve to histamine was obtained.

\section{The effect of verapamil}

In a separate series of experiments, the effect of the calcium voltage-dependent channel antagonist, verapamil, on responses to histamine in the presence of tryptase was investigated in tissues from three patients. The experimental procedure followed was as above, except that in two tissues from each of the three patients, verapamil was added at a bath concentration of $10^{-6} \mathrm{M}$ approximately $15 \mathrm{~min}$ before the addition of $90 \mathrm{ng} \cdot \mathrm{mL}^{-1}$ tryptase. In addition, in another two tissues, in which histamine responses were conducted in the presence of tryptase buffer alone, verapamil $\left(10^{-6} \mathrm{M}\right)$ was also added $15 \mathrm{~min}$ prior to the buffer to assess the effect of the calcium channel antagonist alone on histamine responses. Histamine cumulative concentration-response curves were also performed in the presence of the vehicles used for verapamil and tryptase, i.e. water and tryptase buffer, respectively.

\section{Drugs and chemicals}

Antigen extracts of Dermatophagoides pteronyssinus standardized mite DP 30,000 bioequivalent allergen units (BAU. $\mathrm{mL}^{-1}$ ), Timothy Phleum pratense 1:20 w/v, Alternaria tenuis $1: 10 \mathrm{w} / \mathrm{v}$ and cat pelt $10,000 \mathrm{BAU} \cdot \mathrm{mL}^{-1}$ were obtained from Miles Laboratories Inc. (Elkhart, IN, USA) and stored at $4^{\circ} \mathrm{C}$. Stock solutions of histamine acid phosphate, acetylcholine perchlorate, verapamil hydrochloride and bovine lung heparin sodium salt (149 United States Pharmacopeia (USP) units $\cdot \mathrm{mg}^{-1}$ ) were prepared in distilled water and stored at $-20^{\circ} \mathrm{C}$. Dilute solutions of histamine were prepared in Krebs-Henseleit solution on the day of the experiment and kept on ice. All drugs and chemicals, other than allergens, were purchased from the Sigma Chemical Co. (St. Louis, MO, USA).

\section{Analysis of results}

All responses to histamine were expressed both as a value in milligram tension and as a percentage of the contraction to the maximal concentration of acetylcholine in that tissue. Where duplicate responses were obtained within the one experiment, a mean value was derived for that treatment. In each tissue in each experiment, the concentration of histamine producing half the maximal response (EC50) and thence the negative log value 
of EC50 $\left(\mathrm{pD}_{2}\right)$ was obtained from the response curve. Data were analysed using the Student's t-test, linear regression or analysis of variance (ANOVA) with Fisher protected least squares difference (PLSD) to compare entire curves and then responses at specific concentrations of histamine. Differences were considered significant at a p-value equal to or less than 0.05.

\section{Results}

Tissues from seven patients contracted in response to antigens, and these were considered sensitized, whereas tissue from the other four patients failed to respond to the application of any of the four allergens, and these were designated as nonsensitized. Responses were consistent within tissues from the same patient. The magnitude of the response to antigen was highly variable between patients and ranged 433-1,500 mg, which represented $25-155 \%$ of the maximal response to acetylcholine in tissues from that patient.

Figure 1 shows the spectrophotometric assay of human tryptase activity. The concentration of active tryptase was calculated using the absorbence rate of $0.096 \mathrm{ab}-$ sorbence units. $\mathrm{min}^{-1}$ and the specific activity conversion factor derived from SCHWARTZ and BRADFORD [16] (i.e. $1 \mathrm{mg} \cdot \mathrm{mL}^{-1}$ human tryptase gives an absorbance rate of change $\cdot \mathrm{min}^{-1}$ of 352 absorbance units at $405 \mathrm{~nm}$ ). After taking the dilution factor (i.e. 500) into account, the concentration of active tryptase was calculated to be 136 $\mu \mathrm{g} \cdot \mathrm{mL}^{-1}$. For addition to the organ bath, tryptase was prepared as $9 \mu \mathrm{g} \cdot \mathrm{mL}^{-1}$ aliquots in a buffer of $10 \mathrm{mM}$ bis-Tris, $\mathrm{pH} 6.1$, with $0.5 \mathrm{M} \mathrm{NaCl}$ and $60 \mu \mathrm{g} \cdot \mathrm{mL}^{-1}$ heparin.

The mean contractions to acetylcholine were $1,610 \pm$ $103(n=4)$ and 2,489 $\pm 564 \mathrm{mg}(\mathrm{n}=4)$ in sensitized and nonsensitized tissues, respectively, and were not significantly different $(\mathrm{p}>0.05)$. There was no change in baseline tone in response to the addition of either tryptase or tryptase buffer solution. All tissues from all patients contracted in response to histamine over a concentration range of $10 \mathrm{nM}$ to $1 \mathrm{mM}$. There was no significant

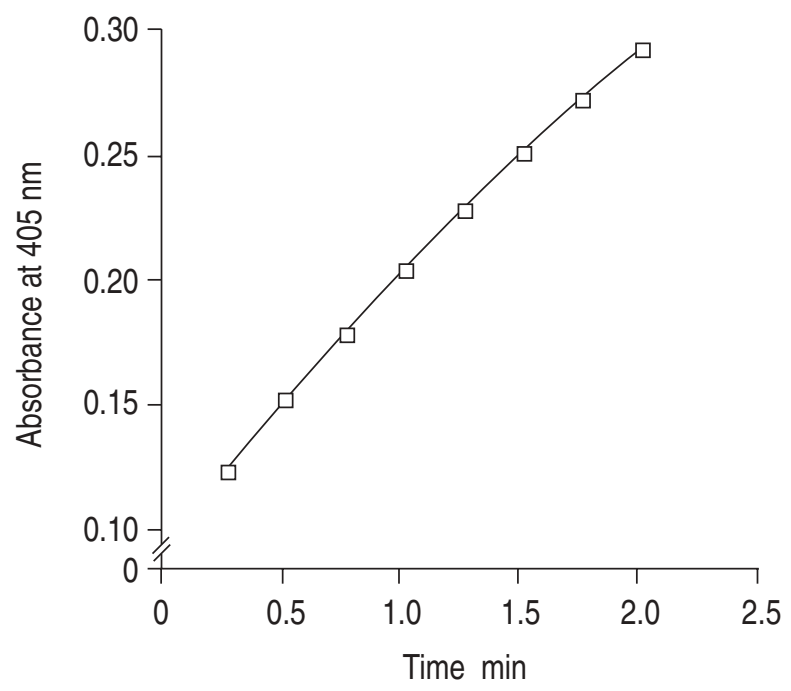

Fig. 1. - Spectrophotometric assay of human tryptase activity, assessed by measuring the rate of hydrolysis of chromogenic substrate at 405 nm. difference between the value for mean maximum tension $(\mathrm{T} \max )(\mathrm{mg})$ in response to histamine in tissue from sensitized patients and that from nonsensitized patients (table 2). However the addition of $90 \mathrm{ng} \cdot \mathrm{mL}^{-1}$ tryptase to sensitized tissues significantly potentiated the contractile response to histamine (fig. $2 \mathrm{a}$ ), while producing

Table 2. - Effect of tryptase on maximal responses to histamine and $\mathrm{pD}_{2}$ values in nonsensitized (NS) and sensitized (S) bronchi

\begin{tabular}{|c|c|c|c|c|c|c|}
\hline & \multicolumn{6}{|c|}{ Tryptase concentration $\mathrm{ng} \cdot \mathrm{mL}^{-1}$} \\
\hline & \multicolumn{2}{|r|}{0} & \multicolumn{2}{|c|}{90} & \multicolumn{2}{|c|}{200} \\
\hline & NS & $\mathrm{S}$ & NS & $\mathrm{S}$ & NS & $\mathrm{S}$ \\
\hline$T_{\max } \mathrm{mg}$ & $\begin{array}{l}2704 \\
(724)\end{array}$ & $\begin{array}{l}1180 \\
(203)\end{array}$ & $\begin{array}{r}2190 \\
(408)\end{array}$ & $\begin{array}{l}1968 \\
(322)\end{array}$ & $\begin{array}{l}2645 \\
(442)\end{array}$ & $\begin{array}{c}1692 \\
(147)\end{array}$ \\
\hline $\mathrm{pD}_{2}$ & $\begin{array}{c}5.53 \\
(0.20)\end{array}$ & $\begin{array}{c}5.49 \\
(0.13)\end{array}$ & $\begin{array}{c}5.70 \\
(0.11)\end{array}$ & $\begin{array}{c}5.51 \\
(0.27)\end{array}$ & $\begin{array}{c}5.73 \\
(0.16)\end{array}$ & $\begin{array}{c}5.71 \\
(0.22)\end{array}$ \\
\hline
\end{tabular}

Values are presented as mean of four experiments, and SEM in parenthesis. Response to histamine is expressed as maximum tension $\left(\mathrm{T}_{\max }\right) ; \mathrm{pD}_{2}$ : negative $\log$ value of the concentration of histamine producing half the maximal response (EC50).
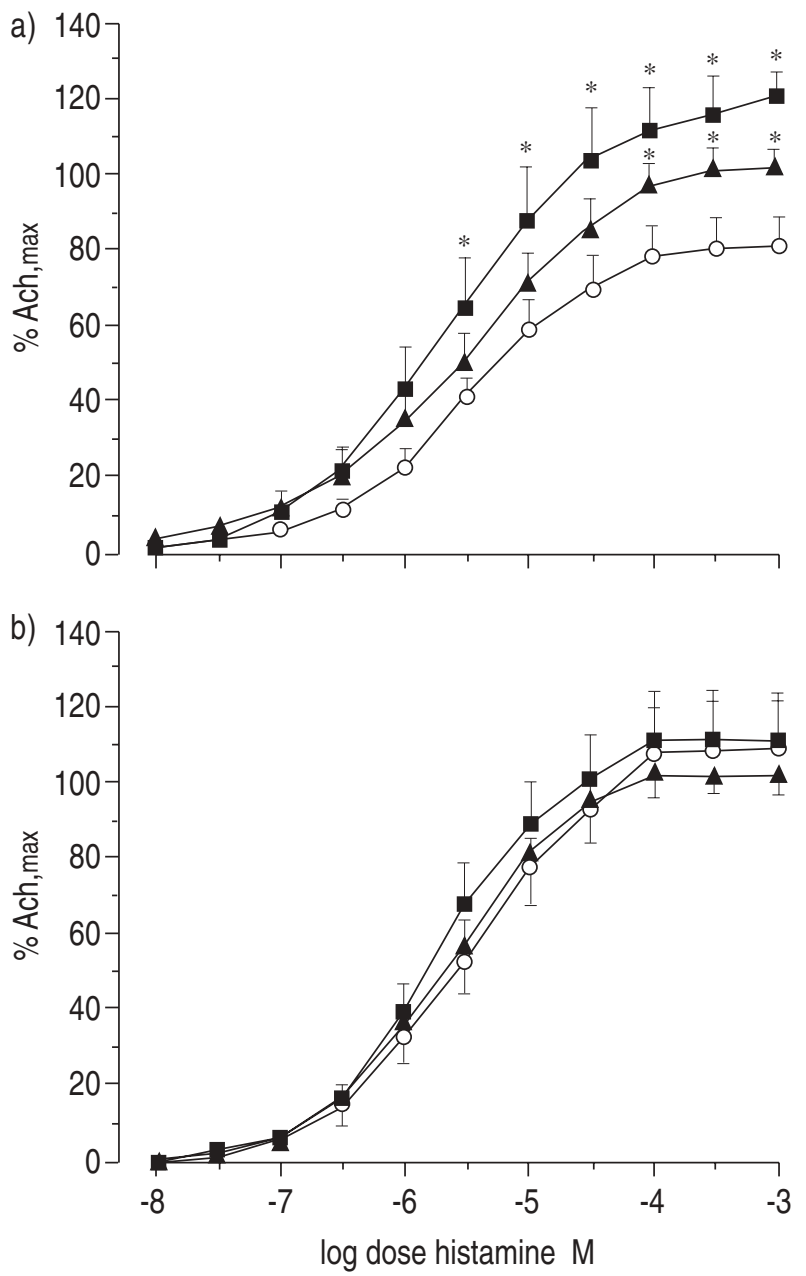

Fig. 2. - Mean cumulative response curves to histamine, expressed as a percentage of the contractile response to a maximum concentration of acetylcholine (\% Ach,max) in: a) sensitized bronchus; and b) nonsensitized bronchus. Mean values from four patients are shown in the absence (O) and presence of $90 \mathrm{ng} \cdot \mathrm{mL}^{-1}(\boldsymbol{\square})$ and $200 \mathrm{ng} \cdot \mathrm{mL}^{-1}(\mathbf{\Delta})$ human purified mast cell tryptase. Values are presented as mean \pm SEM. *: $\mathrm{p}<0.05$, compared to control values. 


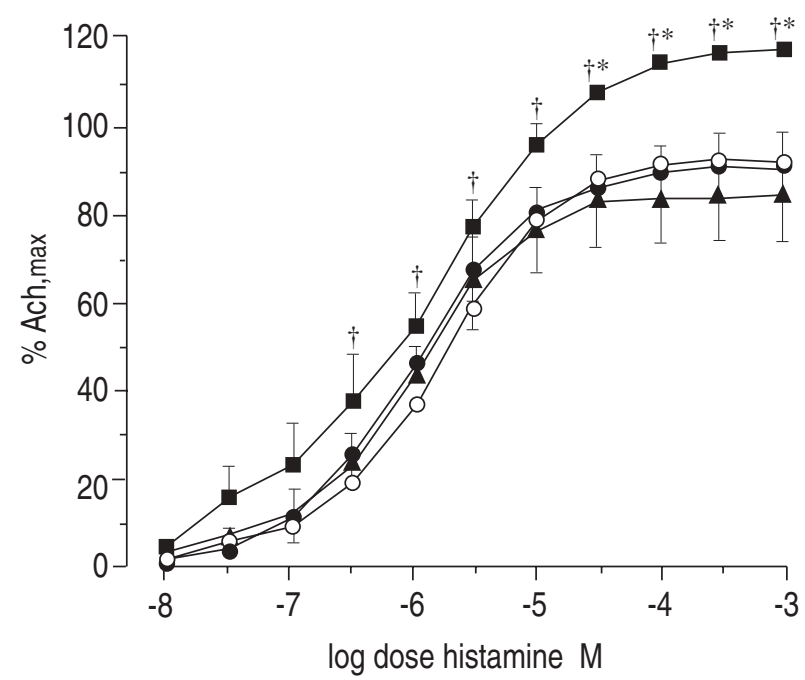

Fig. 3. - Mean cumulative response curves to histamine, expressed as a percentage of the contractile response to a maximum concentration of acetylcholine (\% Ach,max), in sensitized bronchus. Mean values from three patients are shown for histamine in the presence of: tryptase buffer plus the diluent for verapamil water $(O)$; human purified mast cell tryptase, $90 \mathrm{ng} \cdot \mathrm{mL}^{-1}$, plus the diluent for verapamil water (ם); tryptase, $90 \mathrm{ng} \cdot \mathrm{mL}^{-1}$, together with verapamil $\left(10^{-6} \mathrm{M}\right)(\mathbf{\Delta})$; and verapamil $\left(10^{-6} \mathrm{M}\right)$ plus tryptase buffer $(\bullet)$. Values are presented as mean \pm SEM. *: $\mathrm{p}<0.05$, compared to values in absence of tryptase; $\dagger: \mathrm{p}<0.05$, compared to values in presence of verapamil $\left(10^{-6} \mathrm{M}\right)$.

no significant change in the mean $\mathrm{pD}_{2}$ (table 2). Histamine responses, at the highest concentrations, were also increased in the presence of $200 \mathrm{ng} \cdot \mathrm{mL}^{-1}$ tryptase, but to a lesser extent than with the lower concentration of tryptase (fig. 2a). There was no significant change in the $\mathrm{pD}_{2}$ value for histamine in the presence of $200 \mathrm{ng} \cdot \mathrm{mL}^{-1}$ tryptase (table 2). In nonsensitized patients, neither 90 nor $200 \mathrm{ng} \cdot \mathrm{mL}^{-1}$ produced any significant change in contractile responses to histamine (fig. $2 b$ and table 2).

In the presence of verapamil, the tryptase-induced increase in histamine responses was significantly inhibited $(\mathrm{p}<0.05)$ from $117 \pm 2$ to $84.5 \pm 10 \%(\mathrm{n}=3)$ (fig. 3$)$. Verapamil had no significant effect on histamine responses elicited in the presence of tryptase buffer alone (fig. 3).

\section{Discussion}

This study has demonstrated, for the first time, that mast cell tryptase potentiates the contractile response to histamine in human isolated airways. Moreover, this potentiation occurs only in tissues derived from patients whose bronchi exhibit a contractile response to antigen, i.e. which are sensitized. The potentiation was not observed in nonsensitized tissue. The mechanism underlying the tryptase-induced potentiation is related to $\mathrm{Ca}^{2+}$ flux through voltage-dependent channels, since it was inhibited by verapamil.

These findings confirm, in human airways, observations made in canine airways more than 7 yrs ago [8], but with several significant differences. Firstly, SeKizAwa et al. [8] found that dog tissue, regardless of sensitization status, exhibited hyperresponsiveness to histamine, whereas we found that responses were only increased in sensitized tissue, i.e. tissue which responded to antigen. However, no mention was made of the allergic status of the dogs in the study by SEKIZAwa et al. [8], and it is possible that all the mongrel dogs they studied were, in fact, sensitized to a common allergen such as Ascaris. Another difference between our study in human bronchi and that conducted in dog airways, is that we found that responses to histamine were markedly increased without a significant change in sensitivity, whereas in dog bronchus, both sensitivity and efficacy were increased [8].

It is possible that the difference that we observed between sensitized and nonsensitized tissue resulted from the fact that there was a tendency for histamine responses, expressed as a percentage of the maximal acetylcholine response, to be lower in the former than in the latter group, and that potentiation by tryptase restored responses in sensitized tissues to that in controls. However, the difference was not significant and, furthermore, in all experiments, the effect of tryptase was assessed by making comparisons between tissues from the same patient tested in the presence and absence of tryptase, as opposed to between tissues from different patients.

It is often suggested that preoperative medication and indication for surgery may be confounding variables when tissue obtained from patients with a variety of preoperative conditions is acquired. We have recently made an extensive study of reactivity in tissues obtained from patients with very different pulmonary diseases, for which they were receiving a variety of preoperative medications. We compared these with tissue from patients free of pulmonary disease and found that histamine responses from patients with cystic fibrosis, emphysema, $\alpha_{1}$-antitrypsin deficiency, carcinoma and Eisenmenger's syndrome did not differ from those in tissues derived from patients with no pulmonary disease [17]. Thus, it is unlikely that, in the present study, the observed differences could be attributable to preoperative disease state or medication.

In the present study, the increased response in sensitized tissue in the presence of tryptase was not dosedependent, in that potentiation of histamine responses with $200 \mathrm{ng} \cdot \mathrm{mL}^{-1}$ was not significantly greater than that occurring with $90 \mathrm{ng} \cdot \mathrm{mL}^{-1}$. It is possible that there is a form of downregulation occurring at the higher concentrations of tryptase. SEkizawa et al. [8] studied only a single concentration of tryptase $\left(90 \mathrm{ng} \cdot \mathrm{mL}^{-1}\right)$ in full response curves to histamine in canine airways. These authors did find, however, that when they used increasing concentrations of tryptase $\left(3-90 \mathrm{ng} \cdot \mathrm{mL}^{-1}\right)$ there was, in fact, a dose-related increase in the response to histamine. However, these experiments were performed on only single concentrations of histamine $\left(10^{-6} \mathrm{M}\right)$.

The relationship between the concentrations of tryptase studied in the present experiments and those found in situ in human lung can be considered in the following manner. SHAnAhan et al. [18] reported that mast cell density in airways of a size comparable to those studied here, was $3 \times 10^{6}$ cells $\cdot \mathrm{cm}^{3}$, although others have reported lower values, depending on the fixative used and area sampled [19-21]. Eleven micrograms of tryptase is stored in $10^{6}$ cells [22], and subjects with systemic anaphylaxis exhibit serum tryptase levels up to $88 \mathrm{ng} \cdot \mathrm{mL}^{-1}$ [23]. Not all tryptase contained in the mast cell is released after antigen challenge, and once released, tryptase diffuses into the circulation and is cleared. Thus, it would seem that both 90 and $200 \mathrm{ng} \cdot \mathrm{mL}^{-1}$ are concentrations 
of tryptase that are achievable locally in human bronchus in situ after mast cell degranulation has occurred.

This is not the first time that we have found sensitization status to be an important factor in determining human airway responsiveness. We and others [11, 24, 25] have reported that passive sensitization of human bronchus produces an increase in some contractile responses, as well as a decrease in the relaxant response to some agonists. Moreover, in a series of experiments which investigated the effect of supernatants from stimulated neutrophils on responsiveness of human bronchus to electrical field stimulation, responses were potentiated, but only in sensitized tissue [26]. These results, together with those of the current study, would suggest that sensitized tissue, whether this occurs passively or "actively", is primed in some way to produce these heightened contractile responses. The nature of the priming factor(s) merits investigation.

As in our previous studies, in which we examined airway hyperresponsiveness in the light of sensitization status [12, 13], tissues from a single patient exhibited a homogeneous response to antigen, i.e. tissues either contracted or did not. Moreover, based on data collected in large epidemiological studies in the Australian population [14], it is unlikely that the spectrum of antigens used would fail to detect sensitized tissue. The concentrations of antigen used in the present study were based on those used in our previous work, in which we had established dose-response relationships to the antigens and, hence, an optimal, maximal dose to detect sensitization. No information was available to us on the atopic status of the subjects as they did not undergo skin-prick testing prior to surgery. Had these data been available to us, we would still have designated our patients as nonsensitized or sensitized on the basis of their in vitro bronchial response to antigen.

Sekizawa et al. [8] found that the potentiation of histamine contraction by tryptase observed in dogs could be inhibited by a calcium channel antagonist, and suggested that tryptase may cause proteolytic cleavage of a protein within the calcium channel. We also found that verapamil inhibited tryptase-induced potentiation. What was surprising, however, was that verapamil itself did not markedly inhibit histamine-induced contraction, as we had previously observed [27]. This may be a reflection of the sensitization status of the tissue. When we made our original observation that $10^{-6} \mathrm{M}$ verapamil decreased histamine responses [27], we were unaware of the sensitization state of the tissues studied and unaware that it could influence tissue responsiveness. Since then, we have shown that when human bronchus is passively sensitized, verapamil-induced relaxation responses are markedly decreased [13]. If this is also the case in innately sensitized tissue, as used in the present study, then this may explain the decreased efficacy of verapamil in decreasing histamine-induced contraction.

If tryptase released from degranulated mast cells within the airways is involved in the airway hyperresponsiveness associated with asthma, it would be expected that airway tissue taken from asthmatic subjects would be hyperresponsive in vitro. However, in vitro hyperresponsiveness has not been consistently demonstrated in isolated asthmatic airways. The effect of tryptase may not be sufficiently long-lived to demonstrate an effect after tissue removal. Alternatively, multiple factors may contribute to the effects of tryptase, including the constant presence of heparin to stabilize its activity. Thus, in the absence of these stabilizing factors, differences in vitro may not be observed.

In summary, we have demonstrated, for the first time, that human mast cell-derived tryptase potentiates contraction to histamine in sensitized, but not nonsensitized human bronchus. Tryptase is likely to cause these effects, as in the dog, via increased calcium influx through voltage-dependent calcium channels. These data extend the observations made in canine airways to human lung and underline the importance of our previous findings on the association between sensitization status and the demonstration of hyperresponsiveness in vitro.

Acknowledgements: The authors acknowledge the assistance of W.W. Raymond in the purification of the human lung tryptase. They thank the cardiothoracic surgeons, theatre staff and pathologists of Royal Prince Alfred, Royal North Shore and St Vincent's Hospitals, for the supply of, and assistance with, the collection of human lung tissue. They also acknowledge the collaborative effort of the cardiopulmonary transplant team at St Vincent's Hospital.

\section{References}

1. Bai TR. Abnormalities in airway smooth muscle in fatal asthma. Am Rev Respir Dis 1990; 141: 552-557.

2. Bai TR. Abnormalities in airway smooth muscle in fatal asthma: a comparison between trachea and bronchus. Am Rev Respir Dis 1991; 143: 441-443.

3. Goldie RG, Spina D, Henry PJ, Lulich KM, Paterson JW. In vitro responsiveness of human asthmatic bronchus to carbachol, histamine, $\beta$-adrenoceptor agonists and theophylline. Br J Clin Pharmacol 1986; 22: 669-676.

4. De Jongste JC, Mons H, Bonta IL, Kerrebijn KF. In vitro responses of airways from an asthmatic patient. Eur J Respir Dis 1987; 71: 23-29.

5. Schellenberg RR, Foster A. In vitro responses in human asthmatic airway and pulmonary vascular smooth muscle. Int Archs Allergy Appl Immunol 1984; 75: 237-241.

6. Bramley AM, Thomson RJ, Roberts CR, Schellenberg RR. Hypothesis: excessive bronchoconstriction in asthma is due to decreased airway elastance. Eur Respir $J$ 1994; 7: 337-341.

7. Whicker SD, Armour CL, Black JL. Responsiveness of bronchial smooth muscle from asthmatics to relaxant and contractile agonists. Pulm Pharmacol 1988; 1: 2531.

8. Sekizawa K, Caughey GH, Lazarus SC, Gold WM, Nadel JA. Mast cell tryptase causes airway smooth muscle hyperresponsiveness in dogs. J Clin Invest 1989; 83: 175-179.

9. Tanaka RD, Clark JM, Warne RL, Abraham WM, Moore WR. Mast cell tryptase: a new target for therapeutic intervention in asthma. Int Arch Allergy Appl Immunol 1995; 107: 408-409.

10. Mitchell RW, Kelly E, Leff AR. Effect of in vitro preconditioning on tracheal smooth muscle responsiveness. Am J Physiol 1991; 260: (Lung Cell Mol Physiol) L168-L173.

11. Armour CL, Diment LM, Black JL. Relationship between smooth muscle volume and contractile response in airway tissue: isometric versus isotonic measurement. $J$ Pharmacol Exp Ther 1988; 245: 687-691. 
12. Black JL, Marthan R, Armour CL, Johnson PRA. Sensitization alters contractile responses and calcium influx in human airway smooth muscle. J Allergy Clin Immunol 1989; 84: 440-447.

13. Villanove X, Johnson P, Savineau JP, McKay K, Marthan $\mathrm{R}$, Black J. Relaxation in human passively sensitized isolated airways. Am Rev Respir Dis 1993; 148: 107-112.

14. Peat J, Woolcock AJ. Sensitivity to common allergens: relation to symptoms and bronchial hyperresponsiveness in children from three different climatic areas of Australia. Clin Exp Allergy 1991; 21: 573-581.

15. Hartmann T, Ruoss SJ, Raymond WW, Seuwen K, Caughey GH. Human tryptase as a potent cell-specific mitogen: role of signalling pathways in synergistic responses. Am J Physiol 1992; 262: L528-L534.

16. Schwartz LB, Bradford TR. Regulation of tryptase from human lung mast cells by heparin: stablization of the active tetramer. J Biol Chem 1986; 261: 7372-7379.

17. Armour CL, McKay KO, Johnson PRA, Glanville A, Black JL. Responsiveness of human airway tissue obtained from patients with different disease states. J Appl Physiol 1996; 80: 2211-2218.

18. Shanahan F, MacNiven I, Dyck N, Denburg JA, Bienstock $\mathrm{J}$, Befus AD. Human lung mast cells: distribution and abundance of histochemically distinct populations. Int Arch Allergy Appl Immunol 1987; 83: 329-331.

19. Pesci A, Foresi A, Bertorelli G, Chetta A, Oliveri D. Histochemical characteristics and degranulation of mast cells in epithelium and lamina propria of bronchial biopsies from asthmatic and normal subjects. Am Rev Respir Dis 1993; 147: 684-689
20. Di Stefano A, Saetta M, Maestrelli P, et al. Mast cells in the airway mucosa and rapid development of occupational asthma induced by toluene diisocyanate. Am Rev Respir Dis 1993; 147: 1005-1009.

21. Himender MK, Walls AF, Goulding D, et al. Airway effects of local challenge with hypertonic saline in exercise-induced asthma. Am J Respir Crit Care Med 1994; 149: 1012-1019.

22. Schwartz LB, Irani A-M A, Roller K, Castells MC, Schechter NM. Quantitation of histamine, tryptase and chymase in dispersed human T and TC mast cells. $J$ Immunol 1987; 138: 2611-2615.

23. Schwartz LB, Metcalfe DD, Miller JS, Earl H, Sullivan T. Tryptase levels as an indicator of mast cell activation in systemic anaphylaxis and mastocytosis. $N$ Engl $J$ Med 1987; 316: 1622-1626.

24. Marthan R, Crevel H, Guenard H, Savineau J-P. Responsiveness to histamine in human sensitized smooth muscle. Respir Physiol 1992; 90: 239-250.

25. Mitchell RW, Ruhlman E, Magnussen H, Leff AR, Rabe KF. Passive sensitization of human bronchi augments smooth muscle shortening velocity and capacity. Am J Physiol 1994; 267: L218-L222.

26. Anticevich SZ, Hughes JM, Black JL, Armour CL. Induction of hyperresponsiveness in human airway tissue by neutrophils: mechanism of action. Clin Exp Allergy 1996; 26: 549-556.

27. Black JL, Armour CL, Johnson PRA, Vincenc KS. The calcium dependence of histamine, potassium chloride and carbachol-induced contraction of human airways in vitro. Eur J Pharmacol 1986; 125: 159-168. 